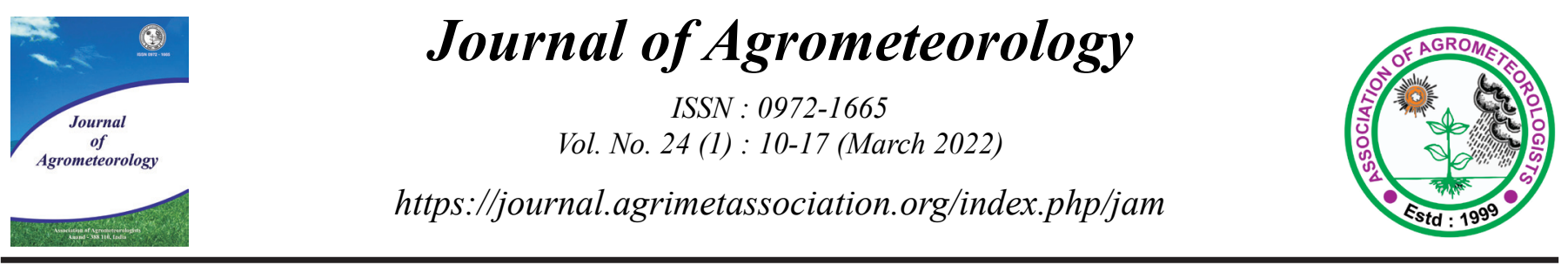

Research Paper

\title{
Seasonal climate forecasts (SCFs) based risk management strategies: A case study of rainfed rice cultivation in India
}

\author{
N.L. KUSHWAHA ${ }^{*}$, JITENDRA RAJPUT ${ }^{1}$, PARESH B. SHIRSATH ${ }^{2}$, D.R. SENA ${ }^{1}$, and INDRA MANI ${ }^{1}$ \\ ${ }^{l}$ Division of Agricultural Engineering, ICAR-Indian Agricultural Research Institute, New Delhi-110012, India \\ ${ }^{2}$ CGIAR Research Program on Climate Change, Agriculture and Food Security (CCAFS), Borlaug Institute for South Asia (BISA), Internation- \\ al Maize and Wheat Improvement Centre (CIMMYT), New Delhi-110012, India \\ * Corresponding author email : nand.kushwaha@icar.gov.in
}

\begin{abstract}
Seasonal climate forecasts (SCFs) have gained popularity in agriculture for climate risk management studies. The available forms of SCFs are not conducive to decision making because of a mismatch in scales over space and time. In this study, available SCFs were disaggregated using the FResampler1 technique to simulate rice yield (cultivar PR 114) under different nitrogen levels and planting dates using DSSAT (Decision Support System for Agrotechnology Transfer) for Sitamarhi district, Bihar, India. Results showed that the late planting of rice predicted the highest yield $\left(3800 \mathrm{~kg}^{-1}\right)$ with high variability under SCF (wet) and $200 \mathrm{~kg} \mathrm{ha}^{-1}$ application of nitrogen fertilizer. Similarly, for SCF (dry), the late planting of rice simulated high yield $\left(3100 \mathrm{~kg} \mathrm{ha}^{-1}\right)$ attributes with $200 \mathrm{~kg}^{-1} \mathrm{of}^{-1}$ nitrogen fertilizer. However, rice yield under climatology $\left(3450 \mathrm{~kg} \mathrm{ha}^{-1}\right)$ was more than SCF (dry) (3100 $\left.\mathrm{kg} \mathrm{ha}^{-1}\right)$. Planting of rice on $15^{\text {th }}$ June 2019 under the SCF (normal) predicted low uncertainty with high mean yields as compared to the mid (05 $5^{\text {th }}$ July 2019$)$, and late $\left(25^{\text {th }}\right.$ July 2019$)$ planting. The present study showed that by applying SCF, we can have a better understanding on "relative" changes in yield attributes with fertilizer doses and planting dates, which may be adopted by the climate adviser to offset the climate risk without compromising productivity.
\end{abstract}

Keywords: FResampler1, climate change, DSSAT, yield, rice, Sitamarhi.।

Rainfed area provides around $58 \%$ of food demand worldwide and plays a major role in the protection of food, fibre and fuel. Rice is one of the principal crop in rainfed regions, it contributes about $25 \%$ of global rice production. Considered as a staple food and pivotal livelihood security, rice nearly feeds $65 \%$ of the Indian population. It is grown in about $43 \mathrm{M}$ ha area with an average productivity of 2.6 tons $\mathrm{ha}^{-1}$. Production of rice is pegged at 102 million tons contributing approximately $40 \%$ of total food grain production. About $70 \%$ of the total rice area is limited to the eastern part of the Indian continent comprising of the states and regions such as Bihar, Chhattisgarh, Jharkhand, Madhya Pradesh, Orissa, Eastern Uttar Pradesh and West Bengal. Due to heavy rainfall in these areas, the crop is often grown under rainfed conditions (Pathak et al., 2020 and Elbeltagi et al., 2020). However, access to improved technologies and some pertinent climatic limitations (https://drdpat. bih.nic.in) the grain yields remain poor somewhere around (1.0-2.0 tons ha- ${ }^{-1}$ for states like Odisha and Bihar) (Pathak et al., 2020).

By developing rainfed agriculture, these areas are known to have tremendous untapped potential for rising production in the future (Singh et al., 2017). The production of rainfed rice is prone to changes in temperature and precipitation due to its climatic dependency. Climate is the main driver of rainfed rice cultivation and its production. Therefore, climate changes, such as those that are expected in the rainfed areas (i.e., increased rainfall variability) may affect the areas for rainfed rice cultivation or may result in yield reduction. The cardinal optimum temperature values of growth of rice is about $25^{\circ} \mathrm{C}$ to $35^{\circ} \mathrm{C}$. While, rice germination requires 22 to $31^{\circ} \mathrm{C}$, anthesis and ripening requires $30^{\circ} \mathrm{C}$ and $23^{\circ} \mathrm{C}$, respectively. A diurnal and nocturnal temperature range of $25-30^{\circ} \mathrm{C}$ and $20-25^{\circ} \mathrm{C}$ is favourable for flowering initiation (Pathak et al., 2020). Rainfall range of $1000-1150 \mathrm{~mm}$ was found to be most favourable to attain the potential yield of rice in a rainfed ecosystem. The optimum humidity during rice crop period is about 60 to $80 \%$ (Pathak et al., 2020 and Singh et al.,2017)with detrimental consequences for rainfed crops that are dependent on natural rainfall (i.e. nonirrigated.

Article info - DOI: https://doi.org/10.54386/jam.v24i1.775

Received: 9 July 2021; Accepted: 6 January 2022; Published online: 11 February 2022

This work is licenced under a Creative Common Attribution 4.0 International licence@Author(s),Publishing right @ Association of Agrometeorologists 
In advent of seasonal climate predictions, considerable efforts have been made to utilise Seasonal Climate Forecasts (SCFs) for managing risks. However, the provision of SCFs alone could not be able to produce actionable evidences for the enhancement of farm-level decisions and interventions at the legislative stage. Lately, various decision-making tools such as crop simulation models were coupled to the SCFs, have shown promise strengthening in the strategic and operational assessments of uncertainties due to contingent behaviour of the climate during the growing seasons (Han et al., 2017). This can offset the risk without compromising with the productivity. One of the legacy tools, CSM-CERES-Rice module of Decision Support System for Agrotechnology Transfer (DSSAT) had demonstrated its capabilities in being integrated to SCFs.

Several investigations in the past had applied crop simulation models using historical daily weather data which could not integrate SCFs due to the mismatch in scales over space and time (Eitzinger et al., 2017; Liu et al., 2017; Ma et al., 2020, Dar et al., 2017; Patel et al., 2006; Patel et al., 2008 and Alejo, 2020)" SCFs provide seasonal climate probability in tercile form which can be used to generate synthetic daily weather files needed for crop models in a forecast mode (Han et al., 2017).

With an obscure reference of use of SCFs in risk management in India and elsewhere, this study employs a coupling strategy of SCF with a crop simulation model (DSSAT with CSMCERES-Rice module) to suggest the best climate risk management options for rice in Sitamarhi, Bihar, India, that belongs to a hot humid climate. The specific objectives include (1) creating an ensemble of daily weather sequences from SCFs to produce crop risk management using DSSAT-CSM-CERES-Rice module and an SCFs variant FResampler1 and (2) to simulate the risk management scenarios in rainfed rice cultivation.

\section{MATERIALS AND METHODS}

\section{Description of the study area}

The district was selected for the study from the rainfed rice cultivation area reported by (Singh et al.,2017)with detrimental consequences for rainfed crops that are dependent on natural rainfall (i.e. non-irrigated. The Sitamarhi is situated in the hot humid area of Bihar, India and has rice-based as principal crop, has been selected as a study area. The district covers an area of about 259.8 ha out of which 122.9 ha area is cultivable. The geographic coordinates of district headquarter are $26^{\circ} 35^{\prime} 14.2764^{\prime \prime} \mathrm{N}$ latitude $85^{\circ} 30^{\prime} 4.2588^{\prime}$ " E longitude. Average annual rainfall in the study area is about $1680.2 \mathrm{~mm}$. The soils of the study area are fine sandy loam, clayey, saline/calcareous and sandy soils. The details of the soil properties are given in Table 1 .

\section{Source of meteorological data}

The daily data of precipitation (PCP), maximum temperature (Tmax), minimum temperature (Tmin), solar radiation (RS) was extracted from the open access gridded data $\left(1^{0} \times\right)^{0}$ grid $)$ provided by IMD (Indian Meteorological Department) using $\mathrm{R}$ software 4.0.5 over the period from 1990 to 2019. The R code was taken from GitHub website (https://github.com/mikejohnson51/ climateR). The monthly average of 30-year metrological data of the study area is presented in Fig. 1.

\section{Seasonal climate forecast}

The climate predictions with sufficient lead time could play vital role in the agriculture. In this study, the SCFs was accessed from the website (https://iri.columbia.edu/) of International Research Institute for Climate and Society (IRI). Four year (2017-2020) and their climatology were simulated, a wet SCF $(20 \% \mathrm{BN}, 20 \% \mathrm{NN}$ and $60 \% \mathrm{AN})$ for JJA (June July August) of 2018, a dry SCF $(60 \% \mathrm{BN}$, $20 \% \mathrm{NN}$ and $20 \% \mathrm{AN})$ for JJA of 2017 , a normal SCF $(20 \% \mathrm{BN}$, $60 \% \mathrm{NN}$ and $20 \% \mathrm{AN})$ for JJA of 2019 and a present SCF $(40 \% \mathrm{BN}$, $30 \% \mathrm{NN}$ and $30 \% \mathrm{AN}$ ) for JJA of 2020 . In this study three different planting dates (15th June, $5^{\text {th }}$ and 25 th, July for every selected SCF) and two applications of nitrogen fertilizer were simulated. The Rice calendar for Sitamrhi district is given in Table 2.

\section{Down scaling of seasonal climate forecast}

A main constraint in integrating crop simulation models and SCFs is the difference in spatio-temporal scales. The inputs for the crop models are meteorological variables, while in case of availability of SFCs is based on seasonal climate data. In this study, FResampler1 was used to downscale the SCFs to daily weather input with the DSSAT model for planning of risk management strategies. A collection of daily meteorological data viz., Tmin, Tmax, rainfall, and RS (solar radiation) from years belonging to a certain type of rainfall terciles [i.e. Below Normal (dry), Near Normal (normal), Above Normal (wet) and present] is taken randomly from historical records for a season of interest. In this way, the covariance of rainfall and other environmental parameters is maintained by FResampler1. since the values of Tmin, Tmax and RS (solar radiation) are conditional on rainfall (Capa et al.,2015 and Han et al., 2017). The seasonal climate forecasts released by the NOAAClimate Prediction Centre, the International Research Institute for Climate and Society (IRI) provided in tercile probabilities.

\section{DSSAT-CSM-CERES-Rice model}

The CSM-CERES-Rice is a physiologically based and management-oriented model embedded in DSSAT v4.5 that utilizes carbon, $\mathrm{N}$, water and energy balance principles to simulate the growth and development of rice plant was applied in the present investigation. The model simulates the growth stage of rice plants on a daily basis, and the final crop yield is computed on the date of harvest. The crop models needs inputs such as plant genetics, plant geometry, planting and harvest dates, fertilizer doses, environmental factors and weather conditions (Ahmad et al.,2012).

Rice cultivars (PR 114) and calibrated genetic coefficients were used for simulation with different SCF, planting dates and fertilizer application (Pathak et al.,2004). The simulation was done for dry (2017), wet (2018), normal (2019) and present (2020) SCF with different planting dates and fertilizer applications.

\section{Constructing management scenarios}

The CSM-CERES-Rice model was applied to generate 
Table 1: Summary of soil properties for the Sitamarhi

\begin{tabular}{|c|c|c|c|c|c|c|c|c|c|c|}
\hline Soil depth $(\mathrm{cm})$ & $\begin{array}{l}\text { Wilting } \\
\text { point } \\
\left(\mathrm{cm}^{3} \mathrm{~cm}^{-3}\right)\end{array}$ & $\begin{array}{l}\text { Field capacity } \\
\left(\mathrm{cm}^{3} \mathrm{~cm}^{-3}\right)\end{array}$ & $\begin{array}{l}\text { Saturated } \\
\text { water } \\
\text { content } \\
\left(\mathrm{cm}^{3} \mathrm{~cm}^{-3}\right)\end{array}$ & $\begin{array}{l}\text { Root } \\
\text { growth } \\
\text { factor }\end{array}$ & $\begin{array}{l}\text { Saturated } \\
\text { hydraulic } \\
\text { conductivity } \\
\left(\mathrm{cm} \mathrm{h}^{-1}\right)\end{array}$ & $\begin{array}{l}\text { Bulk } \\
\text { density } \\
\left(\mathrm{g} \mathrm{cm}^{-3}\right)\end{array}$ & $\begin{array}{l}\text { Organic } \\
\text { carbon } \\
(\%)\end{array}$ & $\begin{array}{l}\text { Clay } \\
(<0.002 \mathrm{~mm}) \\
\%\end{array}$ & $\begin{array}{l}\text { Silt } \\
(0.05 \text { to } \\
0.002 \mathrm{~mm}) \\
\% \\
\end{array}$ & $\begin{array}{l}\mathrm{Ph} \text { in } \\
\text { water }\end{array}$ \\
\hline $10-30$ & 0.14 & 0.28 & 0.53 & 1.00 & 0.32 & 1.52 & 0.41 & 38.6 & 32.1 & 8.1 \\
\hline $30-45$ & 0.14 & 0.28 & 0.53 & 1.00 & 0.32 & 1.52 & 0.40 & 38.6 & 32.0 & 4.5 \\
\hline $45-60$ & 0.17 & 0.28 & 0.58 & 0.50 & 0.23 & 1.52 & 0.31 & 43.1 & 45.6 & 4.0 \\
\hline $90-140$ & 0.19 & 0.32 & 0.60 & 0.27 & 0.20 & 1.51 & 0.29 & 36.1 & 42.1 & 4.4 \\
\hline $140-170$ & 0.17 & 0.29 & 0.29 & 0.23 & 0.18 & 1.46 & 0.26 & 39.1 & 33.1 & 4.9 \\
\hline
\end{tabular}

Table 2: Rice calendar in the Sitamarhi district

\begin{tabular}{llll}
\hline Planting time & Up land & Mid land & Low land \\
\hline Early planting & $3^{\text {rd }}$ week of June & $2^{\text {nd }}$ week of June & $3^{\text {rd }}$ week of May \\
Peak planting & $1^{\text {st }}$ week of July & $3^{\text {rd }}$ week of June & $4^{\text {th }}$ week of June \\
Late planting & $2^{\text {nd }}$ week of July & $1^{\text {st }}$ week of July & $1^{\text {st }}$ week of June \\
\hline
\end{tabular}

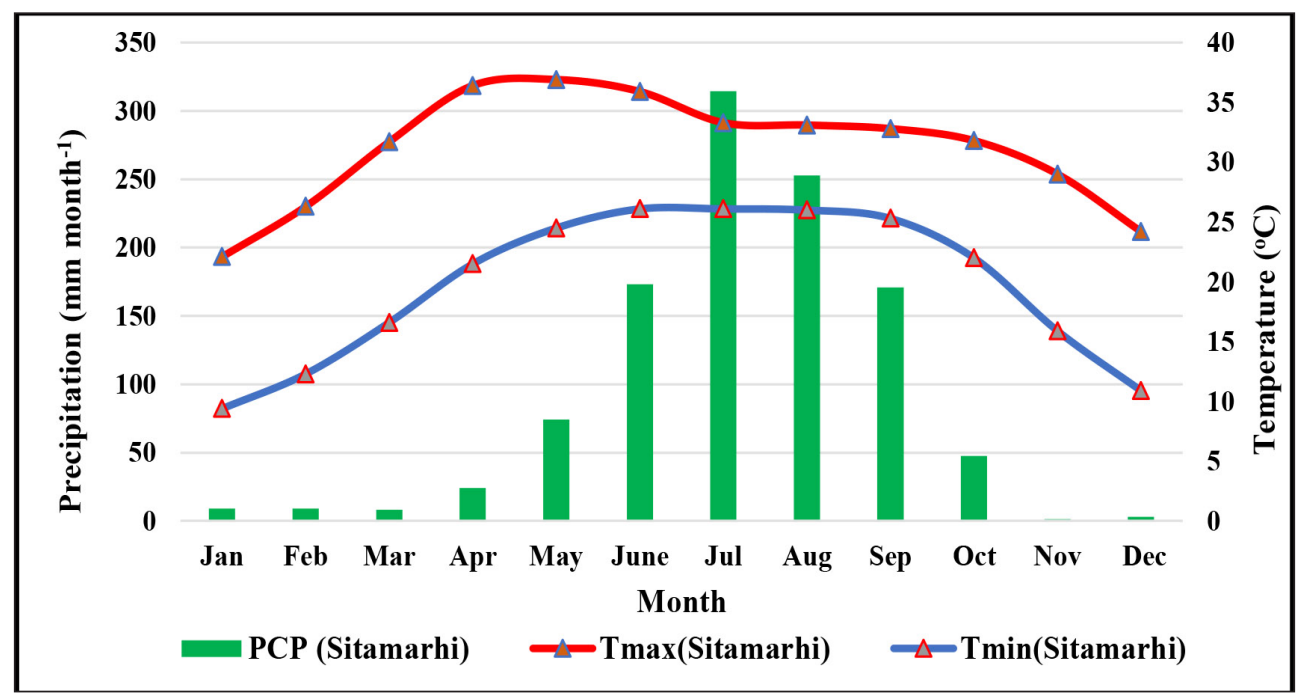

Fig. 1: Monthly variation of principal meteorological parameters in Sitamarhi district

long term simulations of the rice cultivar PR 114 a high yield variety recommended in Sitamarhi, Bihar. The simulations were carried out for 30 years period (1990 to 2019) using the daily meteorological input data reconstructed using FResampler1. A total of 48 scenarios were built that included a factorial combination of 04 SCFs tercile probabilities (Wet, Dry, Normal and Present) as mentioned elsewhere in this manuscript), planting dates [i.e., $15^{\text {th }}$ June (Early), $5^{\text {th }}$ July (Mid) and $25^{\text {th }}$ July (Late)] and N levels (i.e., 80, 120, 160 and $\left.200 \mathrm{~kg} \mathrm{ha}^{-1}\right)$. The scenarios were then assessed using the strategy analysis program of DSSAT to compare percentile distributions for crop yield.

\section{RESULTS AND DISCUSSION}

Effect of different planting dates and fertilizer applications under wet forecast

Effects of different planting dates and fertilizer applications on yields of PT-114 were simulated. The 03 transplanting dates and 04 fertilizer application were simulated under an assumed wet SCF scenario (20\% BN, 20\% NN and $60 \%$ AN for JJA of 2018). Fig. $2 \& 5$ shows the yield forecasts from the different fertilizer applications and planting dates compared with the climatology. SCF (normal climatology) compared over Seasonal Climate Forecast (SCF) scenario (wet), which suggests excess rainfall during cropping season, is likely to have less uncertainty in yield attributes in early and late planting dates. Mid planting yield attributes are comparatively higher in the late planting schedule followed by the early planting schedule. With increase in nitrogen dose, the yield realization also improves and all SCFs and planting schedules have a similar pattern to follow.

The mid planting schedule under normal climatology appears to be a normal-like distribution with high degree of uncertainty suggesting mixed instances of frequent failures and near 
Table 3: Recommended risk management strategies under different tercile based Seasonal Climate Forecast (SCFs)

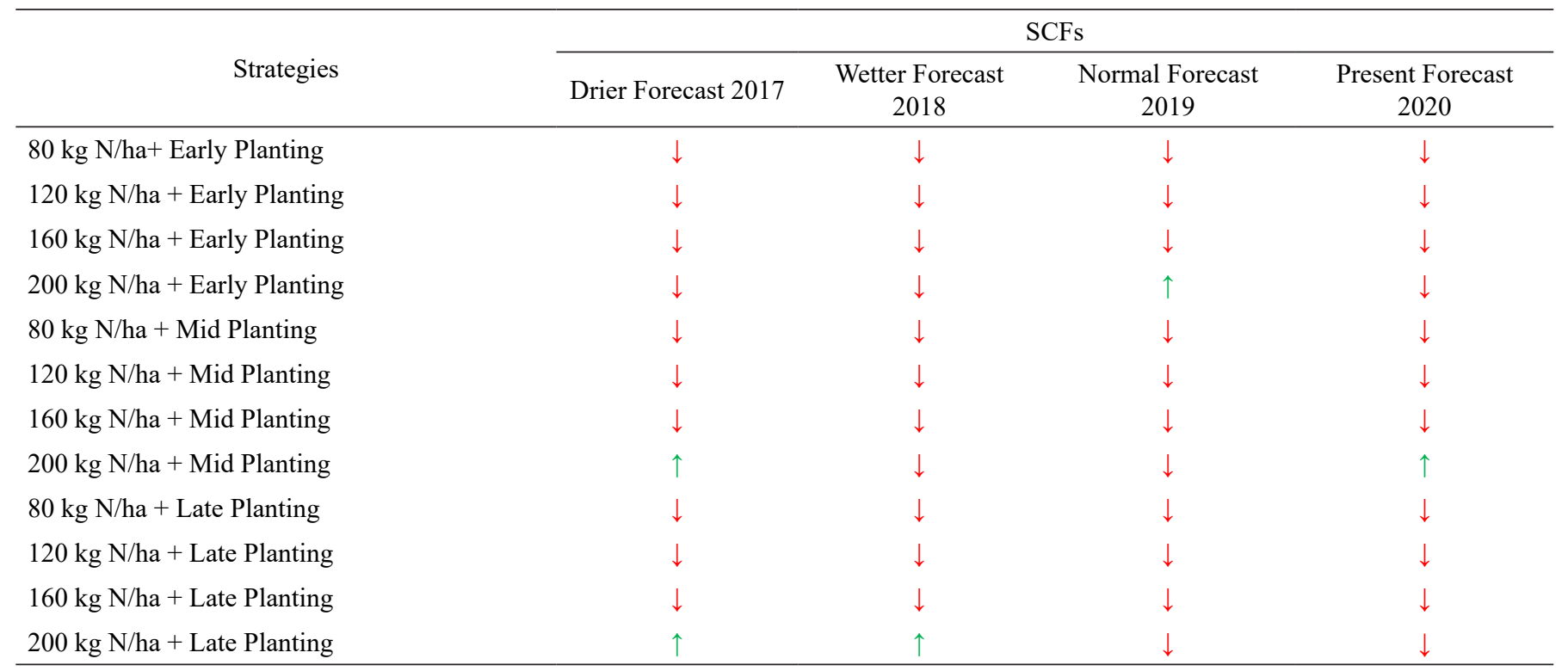

Note: *Risk management strategies; $\downarrow$ : Not recommended, $\uparrow:$ Recommended

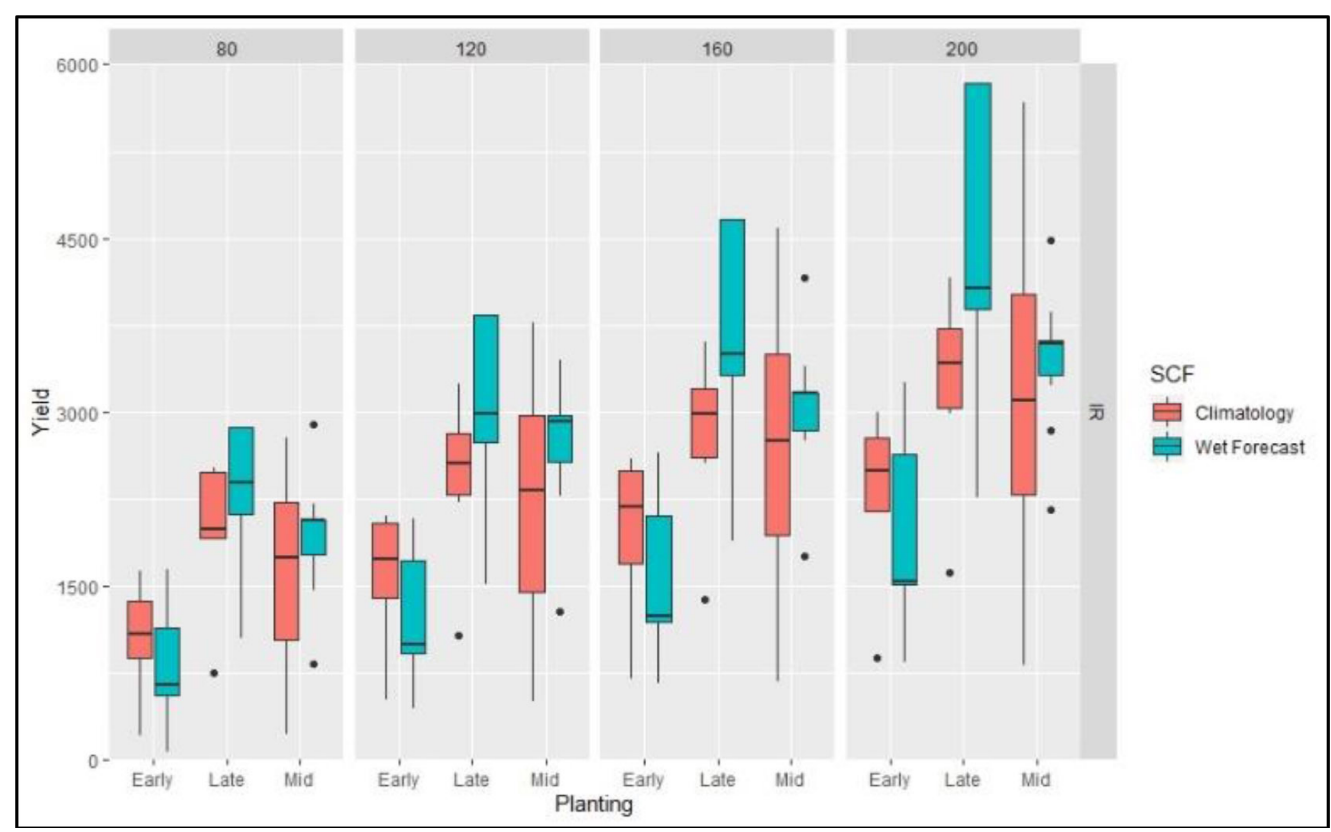

Fig. 2: Box-plot of yield forecasts with different planting for a tercile based wet forecast (20\% BN, 20\% NN and $60 \%$ AN for JJA 2018$)$

potential yield gains. Compared to this, SCF (wet) provides a stable yield range with better affinity of the median yield representing the upper echelon of the yield values. The early planting schedule shows that the normal climatology is better than the SCF (wet) in yield realization in all the nitrogen application rates. The uncertainty in the quartile range (mid $50 \%$ of the cases) is more in SCF (wet) condition than the SCF (climatology) suggests that the intra-year variability is very high in case of SCF (wet).

In the late planting schedule, the likelihood of an SCF (wet) condition is beneficial for yield realization over the normal climatology. This may be due to the reason that the late planting schedule is likely to extend the critical development stages beyond the favourable crop growth window under a normal climatology causing yield penalty, which may be due to an impending water stress. An SCF (wet) scenario probably offset the water stress due to its complimentary wet regime during that critical period. SCF (wet) scenario exhibits a higher uncertainty beyond the median yield values with increase in nitrogen doses. This suggests likelihood of a differential variability of nitrogen due to a wet condition. A potential yield of close to $\sim 6 \mathrm{t} \mathrm{ha}^{-1}$ is achievable in SCF (wet) scenario with a nitrogen dose of $200 \mathrm{~kg} \mathrm{ha}^{-1}$. 


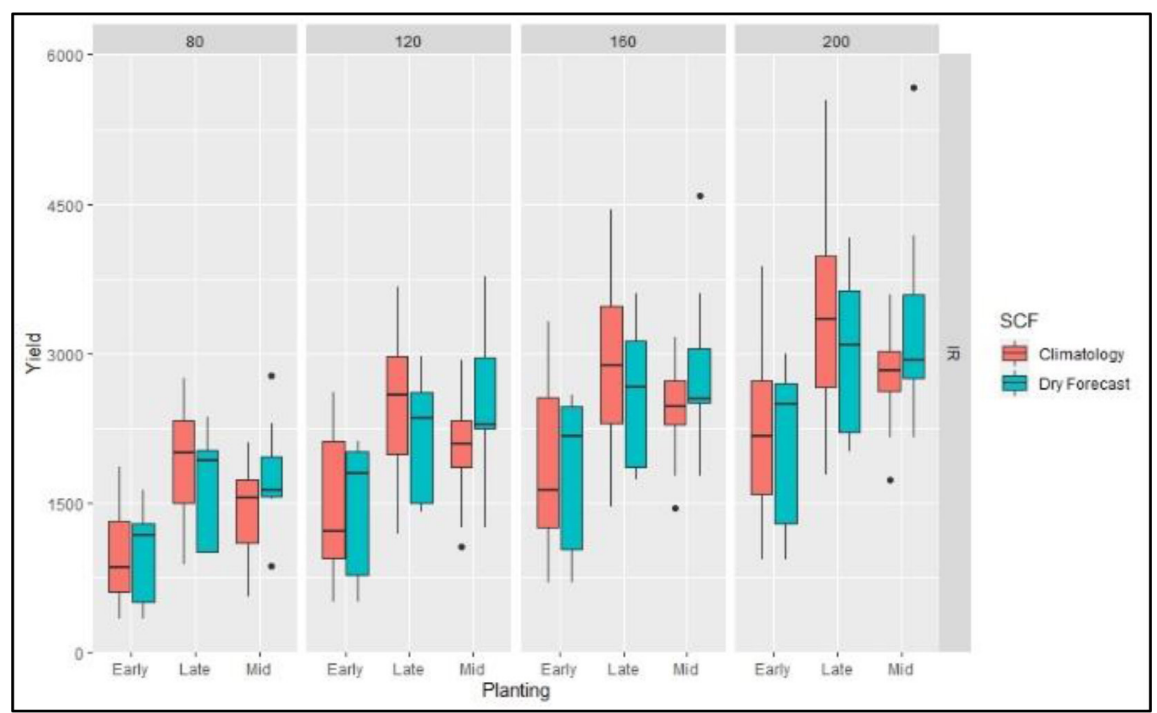

Fig. 3: Box-plot of yield forecasts with different planting windows and different fertilizer application for a tercile based dry forecast (60\% BN, $20 \% \mathrm{NN}$ and $20 \%$ AN for JJA 2017)

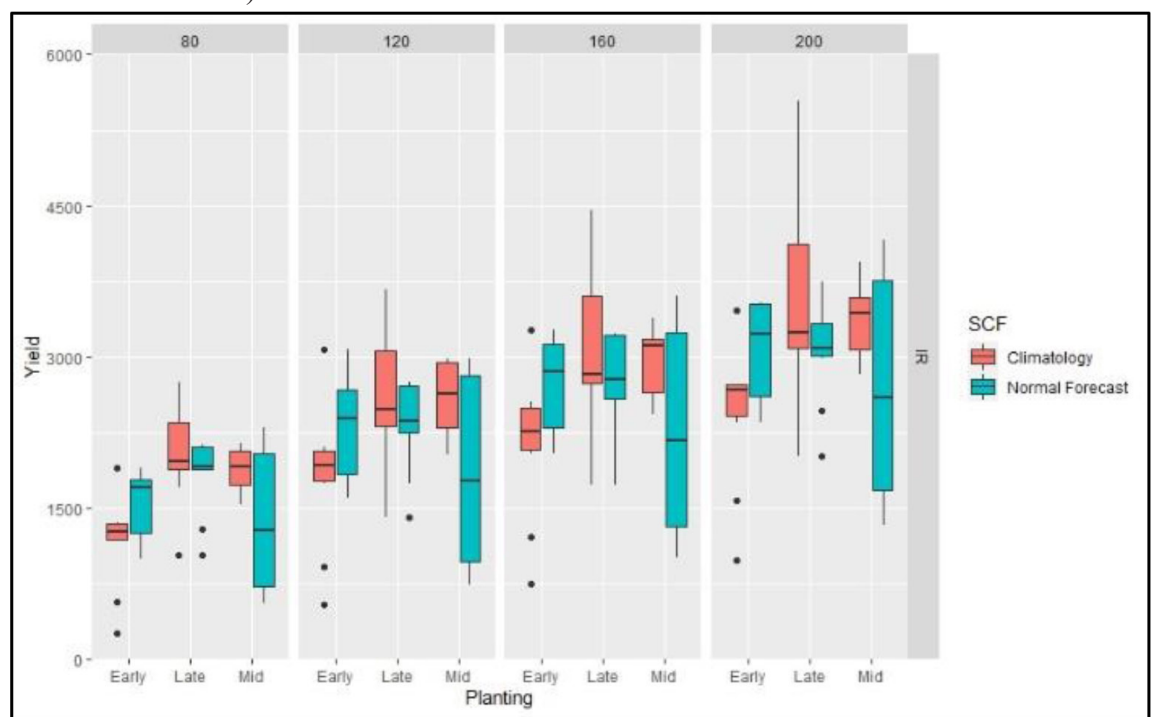

Fig. 4: Box-plot of yield forecasts with different planting windows and different fertilizer application for a normal tercile forecast (20\% BN, $60 \% \mathrm{NN}$ and $20 \%$ AN for JJA 2019).

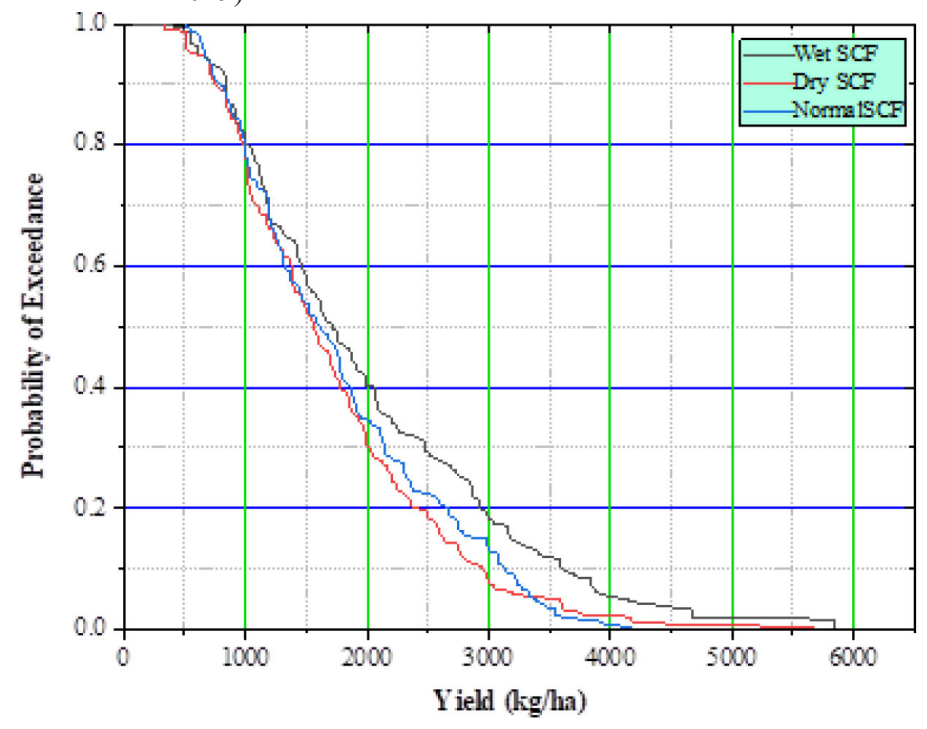

Fig. 5: Eexceedance distribution of yield under the different SCFs 


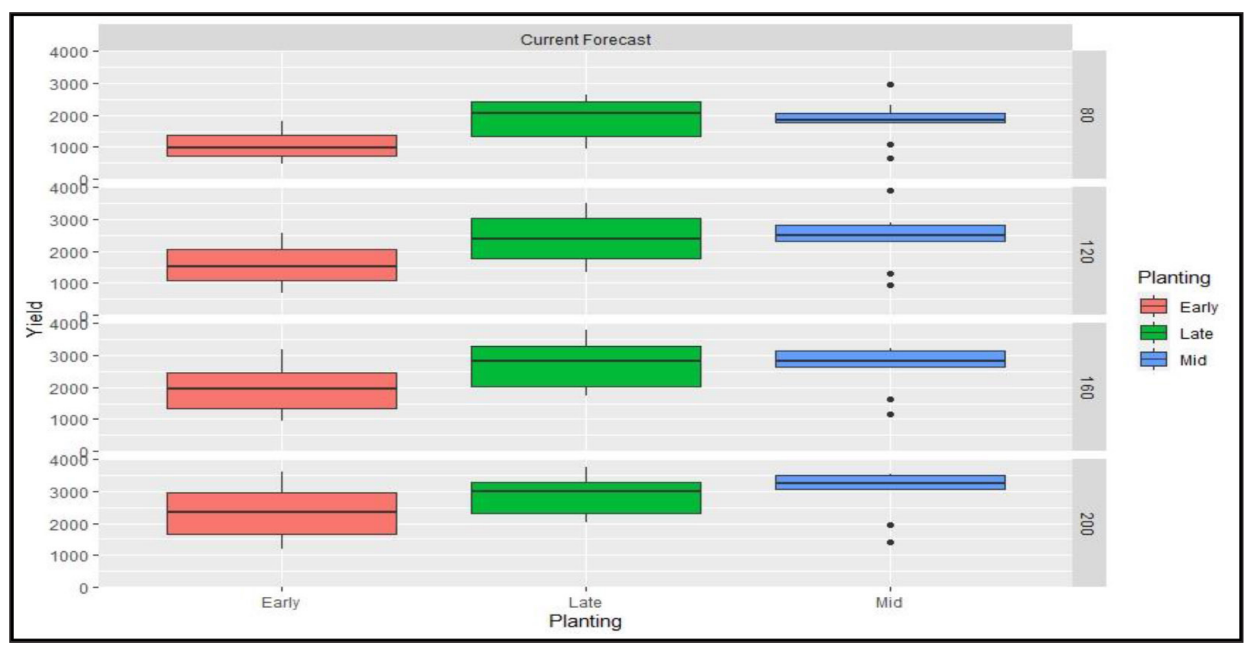

Fig. 6: Box-plot of yield forecasts with different planting windows (Early, Mid and Late) and different fertilizer application (80, 120,160 200 $\left.\mathrm{kg} \mathrm{ha}^{-1}\right)$ for a present tercile forecast $(30 \% \mathrm{BN}, 30 \% \mathrm{NN}$ and $40 \% \mathrm{AN}$ for JJA 2020$)$

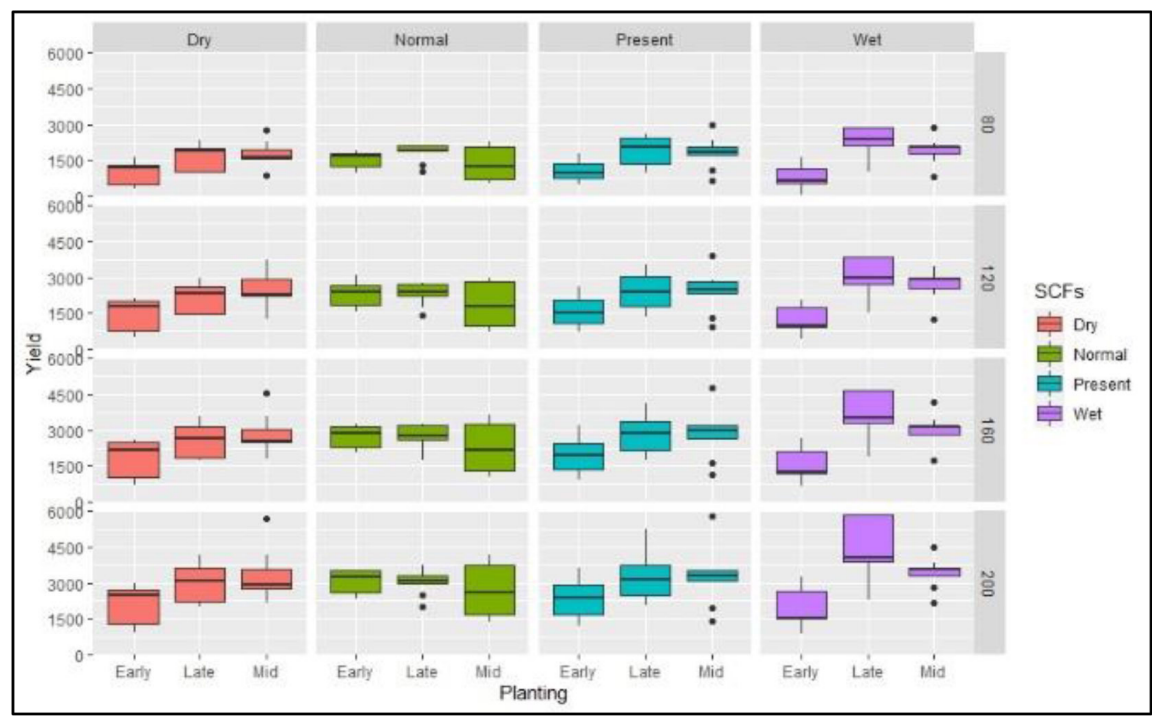

Fig. 7: Comparison of predicted yield box-plot under different SCFs

\section{Effect of different planting dates and fertilizer appliactions under dry forecast}

To see the effect of planting dates and fertilizer application in dry season 2017 and its climatology were simulated with 03 transplanting dates and 04 fertilizer application. The obtained result revealed that early and mid-planting, the likelihood of an SCF (dry) condition is beneficial for yield realization over the normal climatology as shown in Fig. $3 \& 6$. This may be due to the reason that rainfall in the month of July may benefited during the development stage. Lack of irrigation and drier weather, extremely low yields were obtained especially with early- planting. The late plating of rice shows that the normal climatology is better than the SCF (dry) in yield realization in all the nitrogen application rates. This may due the impact of strong solar radiation in the early stages compared to the climatology. Overall late planting of rice obtained higher yield (3100 kg ha $\mathrm{kg}^{-1}$ ) attributes with $200 \mathrm{~kg} \mathrm{ha}^{-1}$ of nitrogen fertilizer followed by the mid planting schedule. However, yield (3450 $\mathrm{kg} \mathrm{ha}^{-1}$ ) under climatology is more than SCF (dry).
Effect different planting dates and fertilizer appliactions under normal forecast

Under SCF (normal), plating dates and fertilizer application were simulated for the JJA 2019. The early planting of rice predicted optimum planting schedule with high yield attribues under SCF (normal) and gave more yield as comapred to climatalogy. However, mid and late plating showed that the normal climatology is better than the SCF (normal) in yield realization in all the nitrogen application rates. From the Fig. $4 \& 5$, it can we seen that the highest yield was predicted with early planting followed by late plating. Lowest yield was predicted under mid plating with high uncertainty.

Effect different planting dates and fertilizer appliactions in present forecast

Diferent risk management scenarios for present SCF (i.e., for 2020) were simulated, to identify the best risk management 
strategies. Result showed that planting of rice on $5^{\text {th }}$ July 2020 under the SCF (present) predicted low uncertainty with high mean yields as compared to the early $\left(15^{\text {th }}\right.$ June 2020$)$ and late $\left(05^{\text {th }}\right.$ July 2020) planting. As shown in Fig. 6, higher predicted mean yield was observed as more fertilizer was applied. However, beyond a threshhold fertilizer level, decrease in yield and gross income may incured.

\section{Overall comparisons of different seasonal climate forecasts (SCFs)}

Comparison of 04 different seasonal climate forecast (SCFs) was done to understand the effect of SCFs in the predicted mean yield. Aa shown in Fig 7, the late planting of rice predicted highest yield (3800 $\mathrm{kg} \mathrm{ha}^{-1}$ ) with high variability under SCF (wet) and $200 \mathrm{~kg} \mathrm{ha}^{-1}$ application of nitrogen fertilizer. Similarly, for SCF (dry), the late planting of rice obtained higher yield attributes with $200 \mathrm{~kg} \mathrm{ha}^{-1}$ of nitrogen fertilizer. However, yield under climatology is more than SCF (dry). When the SCF for JJA 2019 was simulated as a SCF (normal), the planting of rice in the early season predicted high yield (3300 $\left.\mathrm{kg} \mathrm{ha}^{-1}\right)$ with low uncertainty. Late planting $\left(25^{\text {th }}\right.$ July 2020) and $200 \mathrm{~kg} \mathrm{ha}^{-1}$ application of fertilizer under present SCF was predicted high yield (3400 $\left.\mathrm{kg} \mathrm{ha}^{-1}\right)$ with low uncertainty. Recommended risk management strategies under different tercile based Seasonal Climate Forecast (SCFs) are shown in Table 3.

\section{CONCLUSIONS}

In this study, available SCFs were disaggregated using FResampler1 method to run the simulation for the rice yield (cultivar PR 114) for best risk management strategies. Result from this study showed that the late planting schedule, the likelihood of an SCF (wet) condition is beneficial for yield realization over the normal climatology. Under the dry SCF, the early and mid-planting of rice predicted higher yield attributes as compared to climatology. However, late plating of rice showed that the normal climatology is better than the SCF (dry) in yield realization in all the nitrogen application rates. This may due the impact of strong solar radiation in the early stages compared to the climatology. The planting of rice on the $15^{\text {th }}$ June (early planting) under normal SCF showed higher yield attributes with low uncertainty in the yield distribution as compared to its climatology. Based on the predicted yield under different SCFs scenarios, it has been suggested that if the future climate prediction is wet and dry, late planting of rice should be preferred. Whereas, under SCF (normal) future prediction, early planting of rice may offset the climatic risk. The implication of present findings would be helpful in selection of optimum planting dates of rice according to climate prediction for obtaining potential rice yield in the rainfed area. This study also confirms that the tercile based SCFs with DSSAT crop simulation model can be employed for prediction of rice yield precisely.

\section{ACKNOWLEDGEMENTS}

Authors are thankful to the Asia Program Leader, CCAFS, BISA, CIMMYT, New Delhi and Director, ICAR-IARI, New Delhi for their endless help throughout the study.

Conflict of Interest Statement: The author(s) declare(s) that there is no conflict of interest.

Disclaimer: The contents, opinions, and views expressed in the research article published in the Journal of Agrometeorology are the views of the authors and do not necessarily reflect the views of the organizations they belong to.

Publisher's Note: The periodical remains neutral with regard to jurisdictional claims in published maps and institutional affiliations.

\section{REFERENCES}

Ahmad, S., Ahmad, A., Soler, C.M.T., Ali, H., Muhammad, Z.U.H., Anothai, J., Hussain, A., Hoogenboom, G., Hasanuzzaman, M. (2012). Application of the CSMCERES-Rice model for evaluation of plant density and nitrogen management of fine transplanted rice for an irrigated semiarid environment. Prec. Agric.,13:200-218. https://doi.org/10.1007/s11119-011-9238-1

Alejo, L.A. (2020). Assessing the impacts of climate change on aerobic rice production using the DSSAT-CERES-Rice model. J. Water Climate Change, 12 (3): 696-708 https:// doi.org/10.2166/wcc.2020.286

Capa, M., Ines, A., Baethgen, W., Rodriguez-Fonseca, B., Han, E., and Ruiz-Ramos, M. (2015). Linking seasonal climate forecasts with crop models in Iberian Peninsula. Vienna, Austria, p.5278

Dar, M.U.D., Aggarwal, R., and Kaur, S. (2017). Effect of climate change scenarios on yield and water balance components in rice-wheat cropping system in Central Punjab, India. $J$. Agrometeorol., 19(3):226-229.

Eitzinger, A., Läderach, P., Rodriguez, B., Fisher, M., Stephen, B., Kai, S., and Schmidt, A. (2017). Assessing high-impact spots of climate change: spatial yield simulations with Decision Support System for Agrotechnology Transfer (DSSAT) model. Mitig Adapt Strateg Glob Change., 22:743-760. https://doi.org/10.1007/s11027-015-9696-2

Elbeltagi, A., Aslam, M.R., Mokhtar, A., Deb, P., Abubakar, G.A., Kushwaha, N.L., Venancio, L.P., Malik, A., Kumar, N., Deng, J. (2020). Spatial and temporal variability analysis of green and blue evapotranspiration of wheat in the Egyptian Nile Delta from 1997 to 2017. J. Hydrol., 594:125662. https://doi.org/10.1016/j. jhydrol.2020.125662

Han, E., Ines, A.V.M., and Baethgen, W.E. (2017). ClimateAgriculture-Modeling and Decision Tool (CAMDT): A software framework for climate risk management in agriculture. Environ. Modelling \& Software, 95:102-114. https://doi.org/10.1016/j.envsoft.2017.06.024

Liu, H., Liu, H., Lei, Q., Zhai, L., Wang, H., Zhang, J., Zhu, Y., Liu, S., Li, S., Zhang, J., and Liu, X. (2017). Using the DSSAT model to simulate wheat yield and soil organic carbon under a wheat-maize cropping system in the North China Plain. J. Integ. Agric., 16:2300-2307. https://doi. 
org/10.1016/S2095-3119(17)61678-2

Ma, H., Malone, R.W., Jiang, T., Yaob, N., Chenb, S., Songb, L., Fenga, H., Yua, Q., He, J. (2020). Estimating crop genetic parameters for DSSAT with modified PEST software., 115:126017. https://doi.org/10.1016/j.eja.2020.126017

Patel, V.J., Patel, H.R. and Pandey V. (2008). Estimation of wheat yield gap in Anand and Panchmahal districts using CERES-wheat model. J. Agrometeorol., 10 (special issue): 393-397.

Patel, H.R. and Shekh, A.M. (2006). Yield gap and trend analysis of wheat using CERES-wheat model in three districts of Gujarat state. J. Agrometeorol., 8 (1): 28- 39.

Pathak, H., Timsina, J., Humphreys, E., Godwin, D.C., Singh, B., Shukla, A.K., Singh, U., and Matthews, R.R. (2004). Simulation of rice crop performance and water and $\mathrm{N}$ dynamics, and methane emissions for rice in northwest
India using CSM-CERESRice model. CSIRO Land and Water, Griffith, NSW 2680, Australia

Pathak, H., Tripathi,R., Jambhulkar,N.N., Bisen, J.P., and Panda, B.B. (2020). Eco-regional rice farming for enhancing productivity, profitability and sustainability. NRRI Research Bulletin No. 22, ICAR-National Rice Research Institute, Cuttack 753006, Odisha, India. pp 28.

Singh, K., McClean, C.J., Büker, P., Hartley, S.E., and Hill, J.K. (2017). Mapping regional risks from climate change for rainfed rice cultivation in India. Agric. Syst., 156:76-84. https://doi.org/10.1016/j.agsy.2017.05.009

Vilayvong, S., Banterng, P., Patanothai, A., Pannangpetch, K. (2015). CSM-CERES-Rice model to determine management strategies for lowland rice production. Scientia Agricola., 72:229-236. https://doi.org/10.1590/0103-9016-20130380 